\title{
LABORATORY EVALUATION OF NEEM AGAINST THE FIFTH NYMPHAL INSTAR OF Schistocerca gregaria (FORSKAL) \\ Mohamad, E. S. ${ }^{1}$; Th. A. Abdel - Fattah ${ }^{1}$; H. M. Sobhy. ${ }^{2}$ and W. Z. Azer ${ }^{2}$ \\ 1-Locust and Grasshoppers Department, Plant Protection Research Institute, Agric. Res. Center \\ 2- Natural Resources Department, Institute of African Research and Studies, Cairo University
}

\begin{abstract}
Laboratory studied were carried out in an attempt to disclose the effect of antifeedant (Neem) at different concentrations on one day old of the $5^{\text {th }}$ nymphal instar of the desert locust, Schistocerca gregaria (Forskal) by feeding technique. Results showed that Neem caused $42 \%$ mortality after 12 days from treatment of $\mathrm{LC}_{50}$ values. Neem decreased the THC after 2 and 4 days while significant decreased after 6 days compared to control. The free amino acids were non significant between Neem and control after 2 days while significant decreased after 4 and 6 days from treatment. The trehalase was non significant between Neem and control after 2 days while increased after 4 and 6 days from treatment.

Keywords: Schistocerca gregaria, Azaderachtin, Total haemocyte count, Free amino acids, Trehalase.
\end{abstract}

\section{INRODUCTION}

The desert locust, Schistocerca gregaria (Forskal) (Acrididae: Orthoptera) is one of the most important insect pests, because of its polyphagous nature, attacks on a wide range of plants including agricultural crops. The desert locust is an international pest. Efforts have been made to control this cosmopolitan insect through the International Locust Control Organization of the Food and Agriculture Organization (FAO). The bioinsecticides used in this connection are likely to cause an extensive damage to the haemolymph by which toxic chemicals are conveyed from the site of absorption to the organs, where they are metabolized and excreted (Welling \& Paterson, 1985).

The present work aims to study the effect of Neem against the $5^{\text {th }}$ nymphal instar of $S$. gregaria under laboratory conditions. The biochemical effects of Neem on the mortality percentages, total haemocyte count, free amino acids and trehalase.

\section{MATERIALS AND METHODS}

\section{Experimental insects:}

The stock colony of the desert locust, S. gregaria was maintained for several years at the Locust Research Division, Plant Protection Research Institute, Agricultural Research Center, Dokki, Cairo. The insects were reared 
and handled according to (Hunter-Jones, 1961). Fresh clover leaves Alexandranium trifolum Linnaeus were used for feeding the insects in winter and the leaves of leguminous plant, Sesbania aegyptiaca Webster, were introduced during summer.

\section{Chemical under tests:}

Neem:

dihydroazadirachtin).

$$
\text { Neem Force } 0.15 \% \text { EC (Azaderachtin) } \quad\left(\left[22,23-3 h_{2}\right]\right.
$$

\section{3- Bioassays studies and treatment of experimental insects:}

Both sexes of one-day old of the $5^{\text {th }}$ nymphal of $S$. gregaria during synthesis and deposition of the newly adult cuticle (Taha and El-Gammal 1990) were treated by feeding technique with Neem as the following: leaves of $A$. trifolum were dipped in 25, 50 and 100 ppm of Neem for two minutes intervals. Then leaves were air dried before being offered to the nymphs for feeding while the control used was offered leaves treated with distilled water. Three replicates of 20 nymphs were subjected to each of the treated leaves.

After feeding for $24 \mathrm{hr}$ on the treated leaves, the alive nymphs were transferred onto untreated leaves and left to feed for $24 \mathrm{hr}$, after that mortality counts were recorded.

\section{4- Collection of haemolymph:}

Since heat fixation technique proved by many authors to be an excellent one in preventing blood coagulation and preserving the form of haemocytes as they had in circulating blood, this technique was followed as described by (Amin, 1998).

5- Total Haemocyte count:

According to (Wintrobe, 1974).

6- Free amino acids determination:

According to Lee and Takabashi (1966).

7- Determination of Trehalase activity:

According to Ishaaya and Swiriski (1976)

8- Calculations and data analysis:

a) The percentage of nymphal mortality was corrected according to Abbot's formula (Abbot, 1925).

Corrected mortality $=\frac{X-Y}{100-Y} \times 100$

Where: $X=\%$ mortality in treatment.

$Y=\%$ mortality in control.

9- Statistical analysis:

All experiments were conducted in five replicates. Data are presented as means $\pm S D$. Data were subjected to analysis of variance (ANOVA), and Duncon's multiple range test to differentiate between the means at $P<0.05$, using SAS program (SAS, 1988).

$\mathrm{LC}_{25}, \mathrm{LC}_{50}$ values and slope of regression lines were calculated by using (Lpd line) a soft ware for calculating and drawing toxicity lines according to Finney Method (1971). 


\section{RESULTS AND DISCUSSION}

\section{Effects of Neem on S. gregaria by feeding technique:}

\section{Effects of Neem on mortality percentage of S. gregaria:}

Results in Table (1) showed the effect of four concentrations of Neem against $5^{\text {th }}$ nymphal instar of the desert locust, $S$. gregaria.

Data cleared that the percentages of nymphal mortality of the $5^{\text {th }}$ nymphal instar of $S$. gregaria were 24,53, 91 and $98 \%$ after 12 days old treatment with $375,750,1500$ and 3000 ppm of Neem, respectively comparing with control.

The present results in this concern agreed to (Saxena and Khan, 1985); they observed to high mortality rates of the brown plant hopper Nilaparvata lugens Stal. (Homoptera) were caused by higher concentrations of Azt. Some products of $A$. indica exhibited a larvicidal activity in the horn fly Haematobia irritans, stable fly Stomoxys calcitrans and house fly Musca domestica (Miller and Chamberlain, 1989). The oils pressed from seeds of Azadirachtin indica achieved mortality rates of $65-100 \%$ in S. gregaria (Schmutterer and Freres, 1990; Nicol and Schmutterer, 1991). Also, high mortality of $S$. gregaria, red locust Nomadacris septemfasciata and variegated grasshopper Zonocerus variegates was caused by the Neem oil (Schmutterer et al., 1993).

Table (1): Biological effects of Neem on $S$. gregaria by feeding technique:

\begin{tabular}{|l|c|c|c|c|c|}
\hline Days & $\mathbf{3 7 5} \mathbf{~ p p m}$ & $\mathbf{7 5 0} \mathbf{~ p p m}$ & $\mathbf{1 5 0 0} \mathbf{~ p p m}$ & $\mathbf{3 0 0 0} \mathbf{~ p p m}$ & Control \\
\hline $1^{\text {st }}$ & 0 & 0 & 0 & 1 & 0 \\
\hline $2^{\text {nd }}$ & 0 & 0 & 0 & 2 & 0 \\
\hline $3^{\text {rd }}$ & 3 & 0 & 0 & 3 & 0 \\
\hline $4^{\text {th }}$ & 5 & 1 & 0 & 4 & 0 \\
\hline $5^{\text {th }}$ & 3 & 7 & 10 & 19 & 0 \\
\hline $6^{\text {th }}$ & 5 & 14 & 20 & 28 & 0 \\
\hline $7^{\text {th }}$ & 10 & 20 & 28 & 39 & 0 \\
\hline $8^{\text {th }}$ & 12 & 30 & 45 & 47 & 0 \\
\hline $9^{\text {th }}$ & 15 & 39 & 58 & 62 & 0 \\
\hline $10^{\text {th }}$ & 18 & 45 & 64 & 73 & 0 \\
\hline $11^{\text {th }}$ & 21 & 50 & 79 & 89 & 0 \\
\hline $12^{\text {th }}$ & 24 & 53 & 91 & 98 & 0 \\
\hline
\end{tabular}

The data represented in Table (2) and Fig. (1) showed that $\mathrm{LC}_{25}$, $\mathrm{LC}_{50}$ and $\mathrm{LC}_{90}$ of Neem were 326, 589 and 1806 respectively, and slope values $=2.6$. 
Table (2): The $L C_{25}, L C_{50}$ and $L C_{90}$ values of the $5^{\text {th }}$ nymphal instar of the S. gregaria treated by Neem:

\begin{tabular}{|l|c|c|c|}
\hline LC & Con. ppm & Lower limit ppm & Upper limit ppm \\
\hline 25 & 326.3648 & 164.6631 & 437.577 \\
\hline 50 & 588.769 & 367.4418 & 891.0526 \\
\hline 90 & 1806.4377 & 1406.6525 & 4131.3478 \\
\hline
\end{tabular}

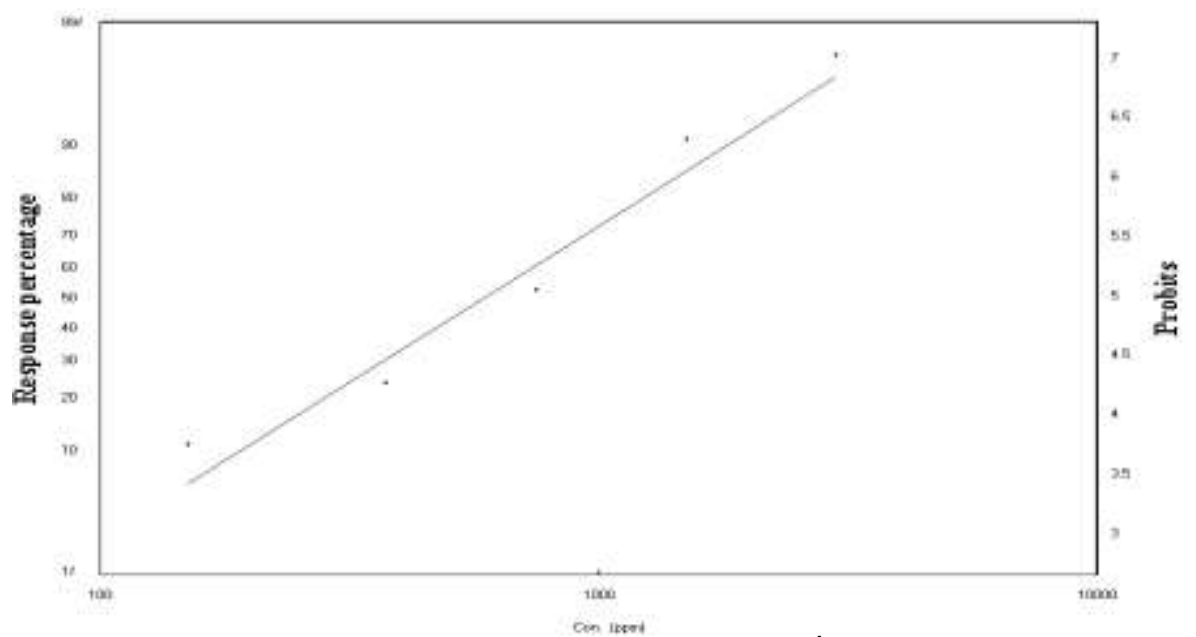

Fig. (1): The $L C_{25}, L C_{50}$ and $L C_{90}$ values of the $5^{\text {th }}$ nymphal instar of the S. gregaria treated by Neem.

\section{Biochemical effects of Neem on S. gregaria by feeding technique:}

The effects of bioinsecticides, Neem with LC $_{50}$ values 589 ppm, after 2, 4 and 6 days after treatment, while control were treated with distilled water.

\section{Determination of total haemocyte count:}

The total haemocyte count (THC) were recognized, in Table (3) showed the fluctuation of the calculated mean number of THC in the haemolymph of the $5^{\text {th }}$ nymphal instar of $S$. gregaria as a result of bioinsecticides treatments. The THC were clearly affected by the tested bioinsecticides. Neem showed highly significant decreased the THC 10670, 1246 and 1115 cells per $\mathrm{cm}^{3}$ after 2, 4 and 6 days of treatment compared to control 3240,2706 and 2210 cells per $\mathrm{cm}^{3}$.

Similarly (Halouane et al., 2001) noted reductions in the haemocyte's numbers after infection of adult of migratory locust $L$. migratoria by Beauvaria bassiana. Xia et al. (2000) have recorded a decline in the total haemocyte count and a marked reduction in the proportion of plasmatocytes and coagulocytes after inoculation of mature adult males of the desert locust infected with Metarhizium anisopliae var. acridium.

The present result in this concern agreed to the results of (Gad and Abdel-Mageed, 2006); they observed that Spinosad and Proclaim decreased 
the THC. Starvation effect has also been reported to increase the THC in Prodenia eridania (Rosenberger and Jones, 1960). The main active constituent of Neem gold is azadirachtin, a tetranortriterpenoid which is a strong antifeedent and also acts as a potent growth inhibitor at microgram levels (Schmutterer, 1990). Ayyangar and Rao (1990) recorded a steep fall in $\mathrm{THC} / \mathrm{mm}^{3}$ (percentage reduction 64 ) after $72 \mathrm{hr}$ of injection of azadirachtin to the last instar larvae of $S$. litura Fab., whereas reduction in THC was observed to be $49.95 \%$ after $72 \mathrm{hr}$ of oral feeding of $1500 \mathrm{ppm}$ of Neem gold. In Periplaneta americana (Qadri and Narsaiah, 1978), injection of azadirachtin to the last instar nymphs results in $20-25 \%$ decrease in haemocytes after $24 \mathrm{hr}$ of treatment. These findings clearly bring forth the efficacy of the botanical in drastically lowering down the counts. The initial triggering in THC after $24 \mathrm{hr}$ of treatment was due to the starvation effect. The decrease in THC was observed after 48 to $72 \mathrm{hr}$ due to the biological effects induced by Neem gold. The THC came down from 27, 894 to 14, 528 at $1500 \mathrm{ppm}$ of Neem gold after $72 \mathrm{hr}$ of treatment (Sharma et al., 2003).

Table (3): The effect of Neem on THC of the $5^{\text {th }}$ nymphal instar of $S$. gregaria, (the number of cells per $\mathrm{cm}^{3}$ ).

\begin{tabular}{|l|c|c|c|}
\hline & Neem & Control & LSD \\
\hline THC 2 days & $1670 \mathrm{~d}$ & $3240 \mathrm{~b}$ & 287.7 \\
\hline THC 4 days & $1246 \mathrm{~d}$ & $2706 \mathrm{~b}$ & 245.3 \\
\hline THC 6 days & $1115 \mathrm{~d}$ & $2210 \mathrm{~b}$ & 229.8 \\
\hline
\end{tabular}

F: Measurement of distance between individual distributions.

Means with the same letter are not significantly different.

Means with the same letter are not significantly different and $a==^{\star \star \star \star}, b={ }^{* \star \star}, c==^{\star \star}, d={ }^{\star}$

\section{Determination of Free Amino Acids:}

Data in table (4) show that, the free amino acids non significant between Neem (5.69) and control (5.61) $\mu \mathrm{g}$ alanine per gm body weight after 2 days while significant decreased after 4 and 6 days 5.7 and $9.76 \mu \mathrm{g}$ alanine per gm body weight from treatment.

This result agrees with those obtained by Bakr (1986) on $M$. domestica after feeding the two days old larvae $1 \mathrm{ppm}$ of Dimilin, BAY SIR 8514 and Altosid. These IGRs increased of the majority of the free amino acids. The feeding deterrence caused by azadirachtin was manifested by a severely reduced food intake resulting in diminished weight gain compared with controls. This is in general agreement with previous observations (Mordue and Blackwell, 1993). Trumm and Dorn (2000) reported that the reduction of food intake after the azadirachtin treatment was accompanied and probably caused by a prolonged retention of food in the crop and a strongly retarded passage through the midgut. The effects of azadirachtin on gut physiology have been mostly related to efficiency of diet conversion and inhibition of digestive enzymes (Koul et al., 1996). Timmins and Reynolds (1992) showed that Azadirachtin reduced growth of $M$. sexta larvae due to impaired protein digestion by inhibition of trypsin synthesis and/or secretion by midgut cells. Other hypothesis puts forward to explain this phenomenon: reduction in the haemolymph nutrient content, i.e. proteins, lipids and 
carbohydrates. The growth rate of insects is generally more closely correlated with nutrient content in the leaves. Also malformations of nymphs are seen and nymphs developed abnormal. Before nymphs moved slowly and had no appetite. (Mordue and Blackwell, 1993) attributed the direct toxicity and rapid mortality to the combined activities of antifeedancy and insect growth regulatory (IGR) effects.

Table (4):The effect of Neem on free amino acids of the $5^{\text {th }}$ instar nymphs $S$. gregaria, ( $\mu$ g alanine per gm body weight).

\begin{tabular}{|l|l|l|l|}
\hline & Neem & Control & LSD \\
\hline Trehalase 2 days & $439 \mathrm{c}$ & $430 \mathrm{c}$ & 37.0 \\
\hline Trehalase 4 days & $441 \mathrm{c}$ & $351 \mathrm{~d}$ & 34.1 \\
\hline Trehalase 6 days & $399 \mathrm{c}$ & $306 \mathrm{~d}$ & 10.7 \\
\hline
\end{tabular}

F:Measurement of distance between individual distributions.

Means with the same letter are not significantly different and $a={ }^{\star \star \star \star}, b={ }^{\star \star \star}, c={ }^{\star \star}, d={ }^{\star}$

Determination of Trehalase activity:

Data presented in Table (5) cleared that, the trehalase non significant between Neem (439) $\mu \mathrm{g}$ glucose released / $\mathrm{min} / \mathrm{gm}$ fresh weight and control (430) after 2 days while significant increased 441 and $399 \mu \mathrm{g}$ glucose released $/ \mathrm{min} / \mathrm{gm}$ fresh weight after 4 and 6 days from treatment.

This results agree with (Mohamad, 2009) observed increasing consumption of trehalose by the M. anisopliae var. acridum to obtain the sole source of carbon after 24 and $48 \mathrm{hrs}$ from infection. Also (Tanani et al. 2012) showed that the treated of newly molted last $5^{\text {th }}$ instar of the $S$. gregaria was by through fresh plant IGR Tebufenozide caused statistically significant increased to trehalase after 4 days.

Table (5): The effect of Neem on trehalase activity of the $5^{\text {th }}$ nymphal instar of $S$. gregaria $(\mu \mathrm{g}$ glucose released $/ \mathrm{min} / \mathrm{gm}$ fresh weight).

\begin{tabular}{|l|l|l|l|}
\hline & Neem & Control & LSD \\
\hline Free Amino Acids 2 days & $5.69 \mathrm{~b}$ & $5.51 \mathrm{~b}$ & 0.8 \\
\hline Free Amino Acids 4 days & $5.7 \mathrm{~b}$ & $9.07 \mathrm{a}$ & 0.69 \\
\hline Free Amino Acids 6 days & $9.76 \mathrm{c}$ & $13.23 \mathrm{a}$ & 0.68 \\
\hline
\end{tabular}

F:Measurement of distance between individual distributions.

Means with the same letter are not significantly different and $a==^{\star \star \star \star}, b==^{\star \star \star}, c={ }^{\star \star}, d==^{\star}$

\section{REFERENCES}

Abbott, W. S. (1925). A method of computing the effectiveness of insecticide. J. Econ. Entomol., $18: 265-267$.

Amin, T. R. (1998). Biochemical and physiological studies of some insect growth regulators on the cotton leafworm, Spodoptera littoralis (Boisd.). Ph. D. Thesis, Fac. Sci. Cairo Univ. Egypt. 
Ayyangar, G. S. G. and Rao, P. J. (1990). Changes in haemolymph constituents of Spodoptera litura (Fab.) under the influence of azadirachin. Ind. J. Entomol., 52: 69-83.

Bakr, R. F. (1986). Morphogenic and physiological aberration induced by certain IGRs in the house fly, Musca domestica. Ph. D. Thesis, Fac. Sci., Ain Shams Univ. Egypt.

Finney, D. J. (1971). Probit analysis (3 ${ }^{\text {th }}$ Ed.). Cambridge Univ. Press, London.

Gad, A. A. and Abdel-Mageed, A. (2006). Effects of spinosad and emamectin benzoate on the blood picture and DNA structure of the cotton leaf worm Spodoptera littoralis (Boisd.) (Lepidoptera: Noctuidae). Egyp. Sci. Mag., 3 (4): 102-118.

Halouane, F., Benzara, A., Doumandji-Mitiche, B. and Bouhacein, M. (2001). Effet de deux entomopathogènes, Beauveria bassiana et Metarhizium flavoviride (Hyphomycètes,Deuteromycotina) sur l'hémogramme des larves de ème stade et des adultes de Locusta migratoria migratorioides (Orthoptera: Acrididae). J. Orth. Res., 10: 331-334.

Hunter-Jones, P. (1961). Rearing and breeding locusts in the laboratory. Bull. Anti-locust Res. Cent. Lond., 12 pp.

Ishaaya, I. and Swiryski, E. (1976). Trehalase invertase and amylase activities in the black scale Seisstiae oleae, and their relation to host edaptibility. J. Ins. Physiol., 16: 1025-1029.

Koul, O.; Shankar, J. S. and Kapil, S. (1996). Bioefficacy and mode-of-action of some limonoids of salannin group from Azadirachta indica A. Juss and their role in a multicomponent system against lepidopteran larvae Entamol. Exp. Appl., 79: 43 (1996).

Lee, Y. P. and T. Takabashi (1966). An improved colormetric determination of amino acids with the use of ninhydrin. Anal. Biochem., 14: 71-77.

Miller, J. A. and Chamberlain, W. F. (1989). Azadirachtin as a larvicide against the horne fly, stable fly and house fly (Diptera: Muscidae). J. Econ. Entomol., 82 ( 5 ): 1375- 1378.

Mohamad, E. S. M. (2009). The effect of entomopathogenic fungus Metarhizium anisopliae var. acridum on flight muscles in the desert locust, Schistocerca gregaria Forsk. M. Sc. Thesis, Fac. Agric. Cairo Univ. Egypt.

Mordue, L. and Blackwell, A. (1993). Azadirachtin: An update. J. Ins. Physiol., 39: 903-924.

Nicol, C. M. Y. and Schmutterer, H. (1991). Contact effects of seed oil from the neem tree Azadirachta indica (A. Juss.), on nymphs of the gregarious phase of the desert locust, Schistocerca gregaria (Forsk.). J. Appl. Entomol., 111 (2): $197-205$.

Qadri, S. S. H. and Narsaiah, J. (1978). Effects of azadirachtin on the moulting process of last instar nymphs of Periplaneta americana (Linn.). Ind. J. Exp. Biol., 16, 1141-1143.

Rosenberger, C. R. and Jones, J. C. (1960). Current concepts concerning insect haemocytes. Ann. Entomol. Soc. Amer., 53: 351-355.

SAS Institute (1988). SAS/ STAT User's Guide, Ver. 6.03. SAS Institute Inc., Cary, North Carolina. 
Saxena, R. C. and Khan, Z. R. (1985). Effect of neem oil on survival of Nilaparvata lugens (Homoptera: Delphacidae) and on grassy stunt and ragged stunt virus transmission. J. Econ. Entomol., 78: 647- 651.

Schmutterer, H. (1990). Properties and potential of natural pesticides from the neem tree, Azadirachta indica. Annu. Rev. Entomol., 35: 271-297.

Schmutterer, H.; Baumgart, M.; Freisewikel, D.; Langenwald, J. and Nicol, C. M. Y . (1993). The effects of neem oil and other neem products on nymph and resulting adults of Schistocerca gregaria, Nomadacris septemfasciata, Locusta migratoria migratorioides and Zonocerus variegates. J. Appl. Entomol., 116 (2): 178-186.

Schmutterer, H. and Freres, T. (1990). Influence of neem seed oil on metamorphosis, colour and behavior of the desert locust Schistocerca gregaria (Forsk.) and the African migratory locust Locusta migratoria migratorioides (R. \& F.). Zeitschrift Fur Pflanzenkrankheiten Und Pflanzenschutz., 97 (4): 431-438.

Sharma, P. R.; Sharma, O. P. and Saxena, B. P. (2003). Effect of Neem gold on haemocytes of the tobacco armyworm, Spodoptera litura (Fabricius) (Lepidoptera; Noctuidae). Cur. Sci., 84 (5): 690-695.

Taha, G. Z. and El-Gammal, A. M. (1990). Morphogenetic effects of nonterpenoid juvenile hormone analogue. S-31183 on metamorphosis of last nymphal instar of Schistocerca gregaria. Egypt J. Appl. Sci., 5: 7581.

Tanani, M. A.; Ghoneim, K. S. and Hamadah. Kh. Sh. (2012). Comparative effects of certain IGRs on the carbohydrates of hemolymph and fat body of the desert locust, Schistocerca gregaria (Orthoptera: Acrididae). Flor. Entomol., 95 (4): 928-935.

Timmins, W. A. and Reynolds, S. E. (1992). Azadirachtin inhibits secretion of trypsin in midgut of Manduca sexta caterpillars: reduced growth due to impaired protein digestion. Entomol. Exp. Appl., 63: 47-54.

Trumm, P. and Dorn, A. (2000). Effects of azadirachtin on the regulation of midgut peristalsis by the stomatogastric nervous system in Locusta migratoria. Phytoparasitica, 28 (1): 7-26.

Welling, W. and Paterson, K. (1985). Toxicodynamics of insecticides: comprehensive insect physiology, biochemistry and pharmacology, Pergamon Press, $1^{\text {st }}$, ed., 12: 603-645.

Wintrobe, M. M. (1974). Clinical haemcytology. Lea and Febiger. Philadelphia, Pa. ( $7^{\text {th }}$ ed), $1186 \mathrm{p}$.

Xia, P.; Dean, P.; Judge, A. J.; Gillespie, J. P.; Clarkson, J. M. and Charnley, A. K. (2000). Acid phosphatases in the haemolymph of the desert locust, Schistocerca gregaria, infected with the entomopathogenic fungus Metarhizium anisopliae .J. Ins. Physiol., 46: 1249-1257. 


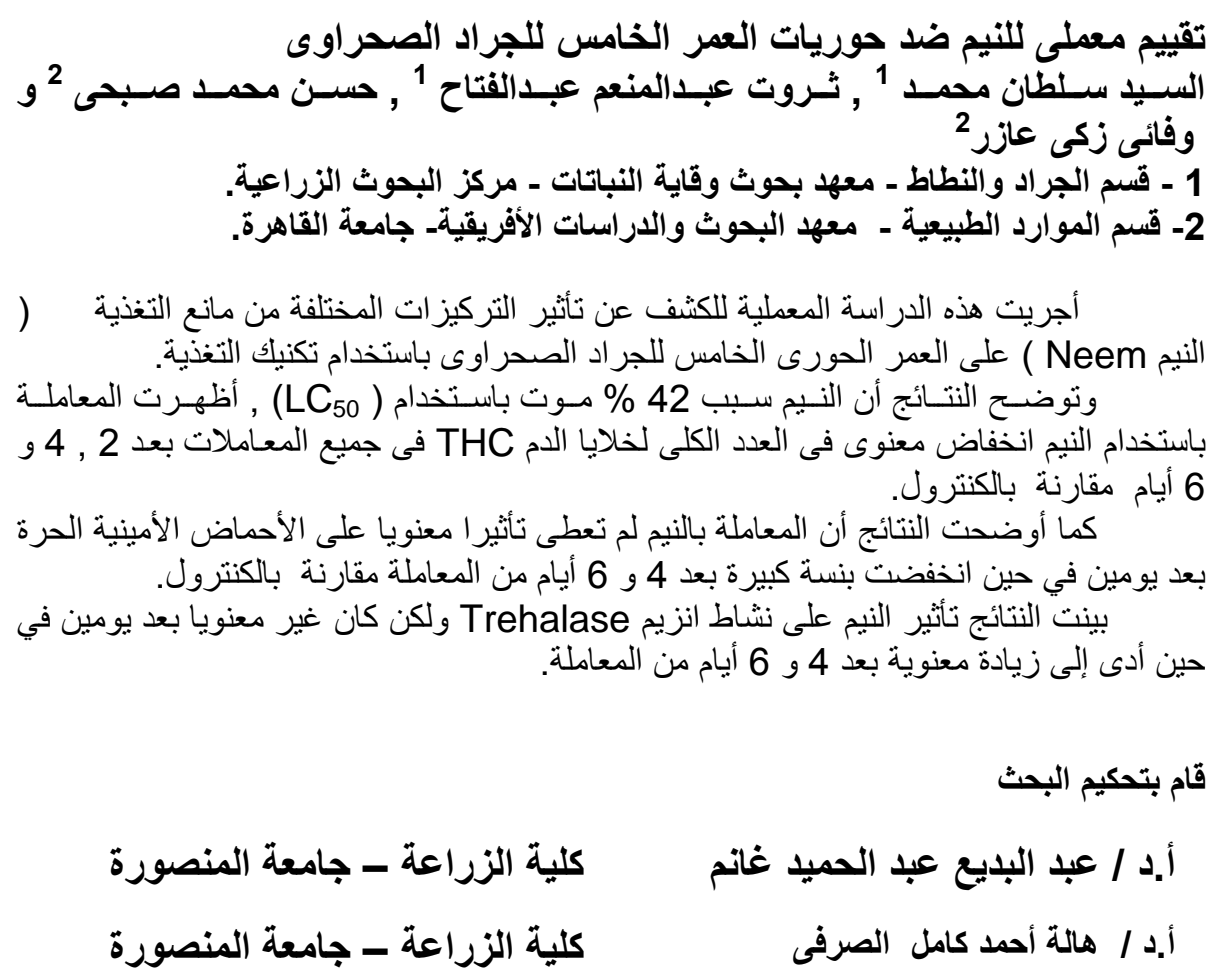

